\title{
Nasal patency and craniocervical posture in scholar children
}

\author{
Patência nasal e postura craniocervical em crianças em idade escolar \\ Permeabilidad nasal y postura craneocervical en niños escolares \\ Jovana M. Milanesi', Luana C. Berwig' ${ }^{2}$ Angela R. Busanello-Stella ${ }^{3}$, Maria Elaine Trevisan², \\ Ana Maria T. da Silva ${ }^{3}$, Eliane C. R. Corrêa ${ }^{4}$
}

\begin{abstract}
Changes in head posture have been observed as a compensatory mechanism for the nasal airflow impairment. This study aimed to compare the craniocervical posture between children with normal and decreased nasal patency and correlate nasal patency with craniocervical posture. Children aging from six to twelve years went through nasal patency and craniocervical assessments. The biophotogrammetric measures of craniocervical posture used were Cervical Distance (CD), Head Horizontal Alignment (HHA) and Flexion-Extension Head Position (FE), evaluated by SAPO software (v.0.68). Nasal patency was measured using Peak Nasal Inspiratory Flow meter (PNIF) and Nasal Obstruction Symptom Evaluation (NOSE) scale. One hundred thirty-three children were distributed into two groups: G1 (normal nasal patency - PNIF higher than $80 \%$ of predicted value) with 90 children; 62 (decreased nasal patency - PNIF lower than $80 \%$ of predicted value) with 43 children. Differences between groups were not found in $\mathrm{CD}$ and HHA measures. FE was significantly higher in $\mathrm{G} 2$ than $\mathrm{G} 1$ ( $\mathrm{p}=0.023$ ). Negative weak correlation between FE and \%PNIF ( $r=-0.266 ; p=0.002)$ and positive weak correlation between CD and PNIF ( $r=0.209$; $p=0.016$ ) were found. NOSE scores negatively correlated with PNIF ( $r=-0.179 ; p=0.039$ ). Children with decreased nasal patency presented greater head extension. This postural deviation is prone to increase as nasal airflow decreases, thus indicating the relationship between
\end{abstract}

craniocervical posture and nasal patency. Lower values of PNIF reflected on additional problems caused by nasal obstruction symptoms

Keywords | Mouth Breathing; Nasal Obstruction; Photogrammetry; Posture.

RESUMO | Mudanças na postura da cabeça têm sido observadas como um mecanismo de compensação para a perda de fluxo de ar nasal. Este estudo teve como objetivo comparar a postura craniocervical entre crianças com patência nasal normal e reduzida e patência nasal correlacionada com postura craniocervical. Crianças de seis a doze anos passaram por avaliações de patência nasal e craniocervical. As medidas biofotogramétricas de postura craniocervical utilizadas foram distância cervical (CD), alinhamento horizontal cabeça (HHA) e flexoextensão da cabeça (FE), avaliadas pelo software SAPO (v.0.68). A patência nasal foi medida utilizando o medidor de pico de fluxo inspiratório nasal (PNIF) e escala de avaliação dos sintomas de obstrução nasal (NOSE). Cento trinta e três crianças foram distribuídas em dois grupos: G1 (patência nasal normal - PNIF superior a 80\% do valor previsto) com 90 crianças; G2 (patência nasal reduzida PNIF menor que 80\% do valor previsto) com 43 crianças. Não foram encontradas diferenças entre os grupos nas medidas CD e HHA. FE foi significativamente superior em $\mathrm{G} 2$ do que em G1 $(\mathrm{p}=0,023)$. Foram encontradas fraca correlação negativa entre FE e \%PNIF ( $r=-0,266 ; p$

'Physical Therapist, PhD in Human Communication Disorders, Universidade Federal de Santa Maria (UFSM) - Santa Maria (RS), Brazil. ${ }^{2}$ Speech Therapist, PhD student in Program of Human Communication Disorders, Universidade Federal de Santa Maria (UFSM) - Santa Maria (RS), Brazil.

${ }^{3}$ Speech Therapist, Professor at the Department of Speech Therapy, Universidade Federal de Santa Maria (UFSM) - Santa Maria (RS), Brazil.

${ }^{4}$ Physical Therapist, Professor at the Department of Physical Therapy, Universidade Federal de Santa Maria (UFSM) - Santa Maria (RS), Brazil. 
= 0,002) e fraca correlação positiva entre CD e PNIF ( $r=0,209$; $p=0,016)$. A contagem NOSE foi negativamente correlacionada com o PNIF ( $r=-0,179 ; p=0,039)$. Crianças com patência nasal reduzida apresentaram maior extensão de cabeça. Este desvio postural é propenso a aumentar à medida que o fluxo de ar nasal diminui, o que indica a relação entre postura craniocervical e patência nasal. Valores mais baixos de PNIF refletem sobre problemas adicionais causados por sintomas de obstrução nasal. Descritores | Respiração Bucal; Nasal Obstruction; Fotogrametria; Postura.

RESUMEN I Los cambios en la postura de la cabeza se han observado como un mecanismo de compensación para el deterioro del flujo de aire nasal. Este estudio tuvo como objetivo comparar la postura craneocervical entre los niños con la permeabilidad nasal normal y reducida y correlacionar la permeabilidad nasal con la postura craneocervical. Los niños de seis a doce años pasaron por evaluaciones de permeabilidad nasal y craneocervicales. Las medidas fotogramétricas de la postura craneocervical utilizadas fueron Distancia cervical (CD), Alineación horizontal de la cabeza (HHA) y FlexiónExtensión de la posición de la cabeza (FE), evaluadas por el software SAPO (v.0.68). La permeabilidad nasal se midió utilizando Medidor de Flujo Máximo Inspiratorio Nasal (MFMI) y la escala Evaluación de Síntomas de Obstrucción Nasal (ESON). Ciento treinta y tres niños fueron distribuidos en dos grupos: G1 (permeabilidad nasal normal - PNIF superior a $80 \%$ del valor predicho) con 90 niños; G2 (la disminución de la permeabilidad nasal - PNIF inferior a $80 \%$ del valor predicho) con 43 niños. No se encontraron diferencias entre grupos en las medidas CD y HHA. FE fue significativamente mayor en G2 que en $\mathrm{Gl}(\mathrm{p}=0.023)$. Se encontraron correlación negativa y débil entre FE y \%PNIF ( $r=-0.266 ; p=0.002)$ y correlación positiva y débil entre CD y PNIF ( $r=0.209 ; p=0.016$ ). Las puntuaciones del NOSE fueron negativamente correlacionadas con PNIF ( $r=-0.179$; $p=0.039$ ). Los niños con baja permeabilidad nasal presentaron una mayor extensión de la cabeza. Esta desviación postural propicia la probabilidad de la disminución del flujo de aire nasal, por lo tanto indica la relación entre la postura craneocervical y la permeabilidad nasal. Valores bajos del PNIF se reflejan en los problemas adicionales causados por síntomas de obstrucción nasal.

Palabras clave | Respiración por la Boca; Obstrucción Nasal; Fotogrametría, Postura.

\section{INTRODUCTION}

Nasal obstruction is a frequent complaint in childhood and consists in the main cause of upper airway resistance increase ${ }^{1}$. Obstructive adenoid and allergic rhinitis may cause not only nasal obstruction but also mouth breathing mode and other consequences ${ }^{2-4}$. The postural compensation for airflow maintenance may target not only the lip and tongue posture, but also the whole body, mainly in morphologically prone patterns ${ }^{3}$.

The postural changes observed in children may determine a worsening in respiratory dysfunction, in which a feedback system may be installed, causing a progressive respiratory and musculoskeletal impairment ${ }^{5}$. The head posture deviation, especially the forward head posture, may cause a compensating mechanism for the normal respiratory function maintenance ${ }^{4,6,7}$. Such alterations, if not corrected, may aggravate respiratory problems or even reflect negatively on adult life $\mathrm{e}^{3,5,8}$. Therefore, the previous detection of postural misalignment and its relation with nasal obstruction may influence not only problem solving, but also the prevention of systemic consequences.
Whenever possible, the usage of objective evaluative methods is indicated. Regarding nasal obstruction, the Peak Nasal Inspiratory Flow (PNIF) has been presented as a reliable method for detecting nasal patency alterations of obstructive and inflammatory etiology, being useful for structural and functional diseases diagnosis ${ }^{9}$. Moreover, the Nasal Obstruction Symptom Evaluation (NOSE) scale is a subjective method used for detecting problems due to nasal obstruction, graduated in scores from zero to $100^{10}$. Biophotogrammetry, a reliable and low-cost method, has been widely used to detect children postural deviation ${ }^{11-13}$.

Literature has not yet presented the relation between nasal obstruction and craniocervical posture with objective evaluations. Based on these considerations, the main goal of this study was to evaluate craniocervical posture in children with normal and decreased nasal patency. Additionally, the correlation between both evaluation methods of nasal patency (objective and subjective) and craniocervical posture was verified. The hypothesis is that nasal patency decrease may be associated with craniocervical posture misalignment, there being a correlation among variables. 


\section{METHODOLOGY}

This study was originated from a project titled "Integrated characterization and evaluation of orofacial motricity and body posture diseases - phase II," approved in the Ethics and Research Committee of Universidade Federal de Santa Maria, under protocol no. 08105512.0.0000.5346 with observational and cross-sectional design.

The sample was obtained from elementary school children. All participants and their parents were informed regarding the procedures, assuring the seal of their identities and physical and mental integrity. Afterwards, they signed the Consent Form, according to 466/12 resolution of Conselho Nacional de Saúde (CNS).

The inclusion criteria were ages from six to 12 years old, mixed or permanent dentition, and normal ventilatory function or obstructive lung disease treated/controlled, verified by spirometry. Spirometric evaluation (One FlowClement Clarke) was carried out, following the American Thoracic Society (1991) ${ }^{14}$ and Sociedade Brasileira de Pneumologia e Tisiologia (SBPT) ${ }^{15}$. The study excluded: children with allergic rhinitis; using antihistaminic and/or oral or topic corticoid therapy on the last thirty days; in orthodontic treatment, physiotherapy or speech therapy; with facial surgery or trauma or evident signs of neurological disease, and/or craniofacial malformation ${ }^{3,12}$. To identify these criteria, a structured interview was conducted with the children's parents.

\section{PROCEDURES}

The selected children were evaluated using photographic recordings with biophotogrammetric analysis, with a software of postural evaluation (SAPO v.0.68). The photographs were taken considering an orthostatic posture in right lateral view. Children were wearing suitable clothing, hair tied back and barefoot for better visualization of anatomic structures. Anatomic points were marked on the subjects' bodies with white Styrofoam balls wrapped with double-sided tape. They were oriented to keep the usual body posture with opened eyes glancing at the horizon line during image acquisition. The scenario for the photographic recordings was constituted by a black background of $3 \times 1.5$ meters, a plumb line suspended on the roof besides the volunteer, a base with 10x40x20 centimeters, with the feet outline drawn on a rubber rug. A digital camera (Sony ${ }^{\circledR}$ Cybershot
7.2 megapixels) connected to a tripod (Vanguard ${ }^{\circledR}-\mathrm{VT}$ 131), with approximately half a child's stature above the floor, was positioned at a distance of at least 3 meters from the subject.

The craniocervical measures used for analysis were (Figure 1):

1) Head Horizontal Alignment (HHA) - angle formed by the tragus, spinous process of the seventh cervical vertebra (vertex) with the horizontal line. Lower values reflected greater forward head posture ${ }^{13}$.

2) Cervical Distance (CD) - horizontal measure from a vertical line tangent by the apex of the thoracic kyphosis and the point at the apex of the cervical concavity. The greater this linear measure, the greater the forward head posture ${ }^{11,13}$.

3) Flexion-extension head position (FE) - formed by the points marked on the spinous process of the seventh cervical vertebra, tragus (vertex) and external palpebral commissure. Greater values mean greater head and upper cervical spine extensions ${ }^{13}$.

In order to assess intra and inter-rater reliabilities, analysis were performed with an interval of one week, by the same research evaluator and also by another experienced evaluator. For this, $10 \%$ of the children evaluated were raffled through random.org website.

For nasal patency assessment, two different methods were used: Peak Nasal Inspiratory Flow (PNIF) and Nasal Obstruction Symptom Evaluation (NOSE). The measure of PNIF was evaluated by using the InCheck Inspiratory Flow Meter (Clement Clarke International, the United Kingdom) with Residual Volume (RV) method, that is, a full exhale followed by a nasal inhale as fast and strong as possible, with closed mouth and well-adapted mask to face ${ }^{16}$. The test was repeated at least three times or until three technically satisfactory measures were obtained, with less than $10 \%$ variation, considering the highest value ${ }^{16}$. The predicted values of PNIF were based on Ibiapina et al. ${ }^{17}$, according to sex and stature.

The NOSE scale is composed of five questions regarding nasal obstruction and how much of a problem it was in the last month. The scores may vary from zero to $100^{10}$, zero meaning no problem and 100 meaning the highest severe problem. The questions were carried out with children and their parents, as the symptoms were not easily detected by the child. 


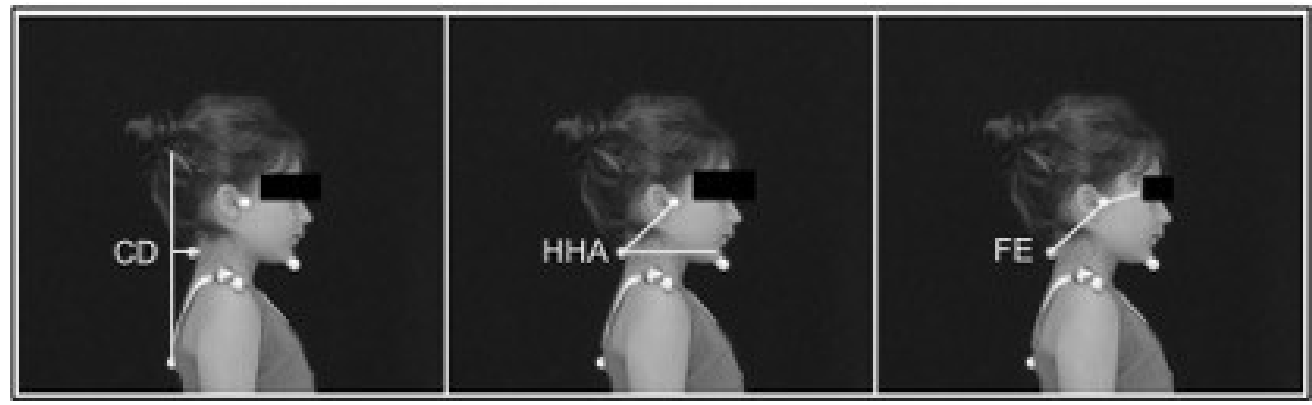

Figure 1. Craniocervical measures

CD: Cervical Distance; HHA: Head Horizontal Alignment; FE: Flexion-extension Head Position

Sample calculation for studies comparing two groups and studies that correlate quantitative variables were performed using the GPower 3.0.10 program. An effect size of 0.8 and power of 0.95 was considered for intergroup comparison, and effect size of 0.5 and power of 0.95 was considered for correlation between variables, both with an alpha of $5 \%$. The minimum number determined was 84 individuals.

\section{Statistical Analysis}

The STATISTICA 9.1 software (Statistica for Windows - release 9.1 Stat Soft) and SPSS (Statistical Package for the Social Sciences) were used for descriptive and inferential data analysis, considering $\mathrm{p}<0.05$ as significant level. Data normality was verified by Lilliefors test. Children were distributed into two groups, considering $80 \%$ of PNIF predicted value, that is, higher than $80 \%$ for Group 1 (G1) and lower than 80\% for Group 2 (G2). To identify whether nasal obstruction is associated with craniocervical posture alterations, the groups were compared through U-Mann Whitney test. The intra and inter-rater reliability of the angular and linear postural measures was tested by the intraclass correlation coefficient (ICC). ICC values below 0.4 are not acceptable, between 0.4 and 0.75 are acceptable, and above 0.75 are excellent ${ }^{18}$. Spearman correlation test was used to correlate craniocervical posture variables with nasal patency and both evaluation methods of nasal patency (objective and subjective), classifying them as strong $(\mathrm{r} \geq 0.7)$, moderate $(0.7<\mathrm{r}>0.3)$, and weak $(\mathrm{r}<0.3)^{19}$.

\section{RESULTS}

The sample was composed of 133 children, 73 boys and 60 girls, with average age of $8.47 \pm 1.61$ years old and
$18.53 \pm 3.41$ of Body Mass Index (BMI). In G1, there were 90 children ( 48 boys and 42 girls), with average age of $8.45 \pm 1.59$ and $18.64 \pm 3.29$ of BMI. In G2, there were 43 children ( 25 boys and 18 girls) with average age of $8.51 \pm 1.65$ and $18.29 \pm 3.68$ of BMI. Both groups were homogeneous regarding age $(\mathrm{p}=0.476)$, sex $(\mathrm{p}=0.572)$, and BMI ( $\mathrm{p}=0.157)$.

The comparison of the postural measures between groups is shown in Table 1. A significant difference between groups was detected in the $\mathrm{FE}$ measure, showing greater head extension in G2. All postural measures presented excellent intra and inter-rater reliability, $(p<0.001)$. In the intra-rater analysis, HHA, CD and FE measures presented ICC values, 0.978 (0.933-0.993), 0.979 (0.936-0.993), and 0.931 (0.800-0.977) respectively. ICC inter-raters presented similar values, with HHA 0.993 (0.980-0.998), CD 0.987 (0.959-0.996), and FE 0.971 (0.914-0.991).

Table 1 - Craniocervical posture measures comparison between G1 and G2

\begin{tabular}{lrrr}
\multirow{2}{*}{ Postural measures } & G1 $(\mathrm{n}=90)$ & $\mathbf{G} 2(\mathrm{n}=43)$ & \\
\cline { 2 - 3 } & Median (IQR) & Median (IQR) & \\
\cline { 2 - 3 } $\mathrm{CD}(\mathrm{cm})$ & $6.0(2.2)$ & $5.6(1.9)$ & 0.784 \\
HHA $\left(^{\circ}\right)$ & $46.0(7.0)$ & $46.0(9.0)$ & 0.992 \\
FE $\left(^{\circ}\right)$ & $147.0(10.3)$ & $152.7(10.4)$ & $0.023^{*}$
\end{tabular}

IQR: Interquartile Range; CD: Cervical Distance; cm: centimeters; HHA: Head Horizontal Alignment; FE: Flexion-extension head position.

*U Mann-Whitney test, $p<0.05$

Negative weak correlation was found between \% PNIF and FE measure (Figure 1), i.e., the smaller the nasal patency, the greater the head extension. The CD was positively and weakly correlated with the PFIN raw value (Figure 2). Negative weak correlation was also found between the scores of NOSE scale and PFIN (Figure 3). 


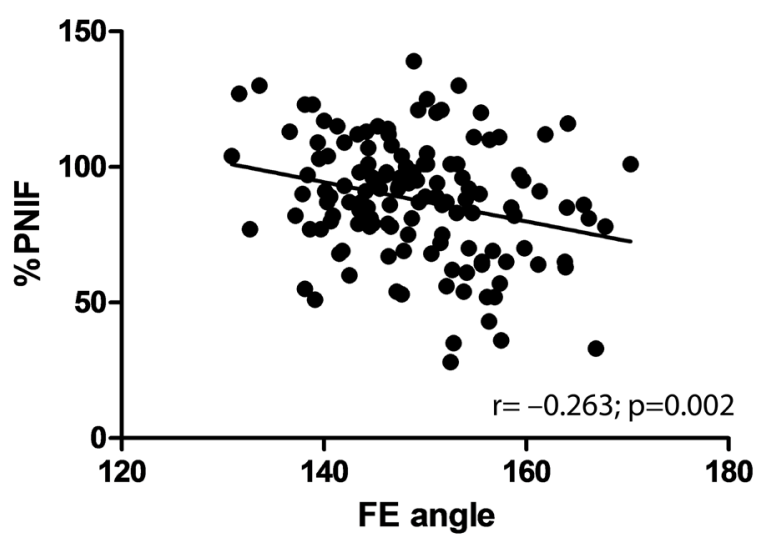

Figure 2. Correlation between \%PNIF and FE angle $\left({ }^{\circ}\right)$

Pearson Correlation Test; $p<0.05$.

FE: Flexion-extension head position; \%PNIF: predicted values of Peak Nasal Inspiratory Flow.

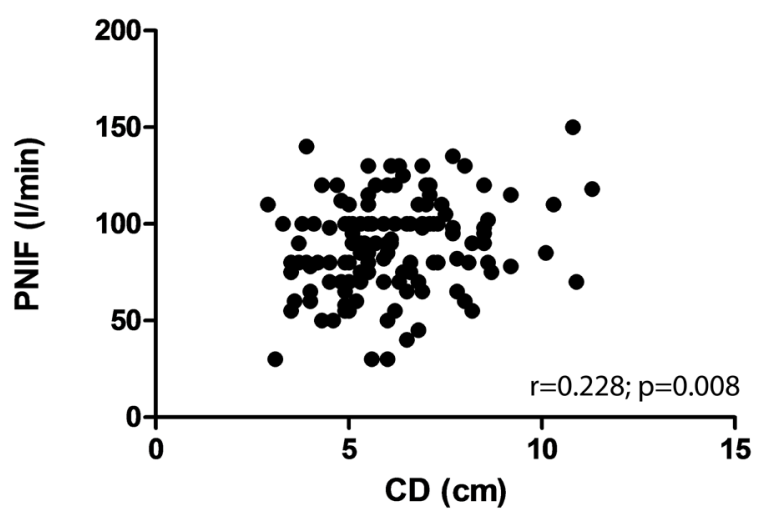

Figure 3. Correlation between PNIF and CD

Pearson Correlation Test; $p<0.05$

PNIF: Peak Nasal Inspiratory Flow; CD: Cervical Distance.

\section{DISCUSSION}

Mouth-breathing children frequently present postural alterations ${ }^{12}$. Such alterations are assumed to be a compensatory mechanism to airflow maintenance ${ }^{6,7}$. Besides that, studies on the relation between nasal obstruction and craniocervical posture with quantitative evaluations were not found in the literature. For being objective and easy-to-use instruments, their applicability is reinforced not only in research, but also in clinical practice.

In biophotogrammetric analysis, children did not differ in HHA and CD measures. Head forward posture is caused by lower cervical spine flexion and upper cervical spine extension. Such postural deviation has been frequently associated with mouth breathing mode, without considering its etiology, whether obstructive or functional. Forward head posture in mouth breathing occurs due to oropharynx rectification to facilitate the air passage in case of nasal obstruction ${ }^{5,6}$. Nevertheless, the association between forward head posture and mouth breathing does not represent a consensus.

In a study comparing nasal-breathing children, obstructive mouth-breathing and functional mouthbreathing children, differences in head posture were not observed in these three groups ${ }^{12}$. The authors suggested that, according to the average values of HHA $(46.15 \times 45.71 \times 45.09)$, all children presented head forward posture. These values were similar to the ones found in all the children $\left(\mathrm{G} 1=45.64^{\circ}\right.$ and $\left.\mathrm{G} 2=45.80\right)$ evaluated in this study. Higher values of this angle were obtained in mouth-breathing children that went through physical therapy for postural treatment, with values of 44 and 47.8 degrees, before and after treatment, respectively ${ }^{20}$.

Despite the absence of difference in HHA measure between groups, the FE measure was greater in G2, with both presenting forward head position. This outcome shows that the smaller the nasal patency, the greater the head extension. Experimental studies have confirmed this condition, observing the correlation between head extension and increase in pharyngeal airway space in healthy adults ${ }^{21}$, and after induced mouth breathing during 15 minutes ${ }^{7}$. Another study has observed five degrees of head flexion after palatal expansion, with increase of airway pharyngeal space in children ${ }^{22}$. Supporting this proposition, mouth-breathing children presented more elevated and extended head in cephalometric evaluation, nevertheless the respiratory mode was confirmed by clinical features and mirror test, and not by the nasal obstruction diagnosis ${ }^{23}$. Another study has concluded that the head extension in response to nasal obstruction can be attributed to a greater activity of the occipital muscles ${ }^{24}$.

Furthermore, this angle was negatively and weakly correlated with the \% PNIF measures. It is important to highlight that this photogrammetric measure $(\mathrm{FE})$ is considered reliable, as it was moderately correlated with a cephalometric measure (CVA), which also assesses the head flexion-extension position. Another measure (CD) was also positively and weakly correlated with PNIF, demonstrating that as nasal patency decreases, the cervical spine curvature also decreases. However, this measure did not differ between $\mathrm{G} 1$ and $\mathrm{G} 2$, and both groups presented values indicating normal cervical alignment ${ }^{11}$.

Based on all these outcomes, for nasal patency maintenance there must be postural compensation such as 
forward head posture and head extension. Overall, forward head was a common postural deviation in children. The extension head is probably the most distinct element between children with and without nasal obstruction.

When analyzing two measures which assess nasal obstruction, objectively and subjectively (PNIF and NOSE scale, respectively), a negative weak correlation was found. These outcomes mean that the smaller the nasal patency, the greater the perception of problems related to obstruction. Melo et al. ${ }^{25}$ have evaluated nasal and mouth-breathing children by Glatzel Mirror and PNIF. They concluded that the Glatzel Mirror could differentiate children with and without nasal obstruction, regardless of its cause. The PNIF differentiated only nasal from surgical mouth-breathing. For this reason, the authors considered the use of this instrument limited. The PNIF percentage, based on reference curve, seems to be a more appropriate measure as an objective indicator because it includes demographic and anthropometric aspects. However, only two studies were found with this measure in adults ${ }^{26}$ and children ${ }^{17}$. More studies including the correlation of \% PNIF and objective measurements, such as acoustic rhinomanometry and acoustic rhinometry, are necessary ${ }^{1}$.

The NOSE scale is more frequently used in septal deviation assessment, in pre and posttreatment in adults ${ }^{10,27,28}$. Regarding the reliability of NOSE scale, the correlations found (NOSE versus rhinomanometry and NOSE versus VAS) were considered good for groups with and without obstruction and for individual measurements over time ${ }^{27}$. Another study in adults with nasal and mouth breathing has found a negative moderate correlation between NOSE and PNIF ${ }^{16}$. The original scale was validated for Portuguese ${ }^{10}$ and other languages ${ }^{27,28}$. However, there is some criticism regarding NOSE, with possible redundancy between items $s^{10,28}$.

Few studies with children were found ${ }^{29,30}$. One of them, evaluated by NOSE score pre and post septoplasty, has obtained average values of 71.0, 22.6 and 23.7 in baseline, three months and 12 months after surgery, respectively ${ }^{30}$. It is important to consider that the use of this instrument in children may have some limitations, as they need their parents help to answer it and because their perception of obstruction symptoms is not very clear. Authors have suggested, for nasal obstruction evaluation, a combination of subjective and objective methods, complementing one another ${ }^{16,25}$.

The hypothesis that children with nasal obstruction present craniocervical posture alteration was partially confirmed, since a greater head extension and the correlation between craniocervical measures and nasal patency were verified. The association found in this study highlights the body posture evaluation of children with nasal obstruction. As head extension is necessary for better air passage through the mouth toward nasal obstruction and may depend on its severity and duration, this postural deviation may last even after the airway patency recovery.

So far, the literature does not present the relation between body posture and mouth breathing though clinical and quantitative evaluations. Therefore, the aim of this study is to demonstrate quantitatively the relation between craniocervical posture and nasal obstruction. Nasal obstruction does not always establish the mouth breathing mode, indicating that the nasal patency measure is more accurate to be related with head posture alterations than with the clinical aspects of mouth breathing.

\section{CONCLUSION}

Children with lower nasal patency have presented greater head extension. PNIF was correlated with craniocervical measures, showing that as nasal patency decreases, head extension increases and cervical spine curvature decreases. These outcomes demonstrated an association between nasal obstruction and head posture. Therefore, therapeutic approach needs to contemplate both aspects.

\section{ACKNOWLEDGEMENTS}

The authors thank Shalina Zanini Cecchin for the English Review.

\section{REFERENCES}

1. Fernandes SSC, Andrade CR, Ibiapina CC. Application of peak nasal inspiratory flow reference values in treatment of allergic rhinitis. Rhinology. 2014;52(2):133-6. doi: 10.4193/ Rhino13.158.

2. Chohan A, Lal A, Chohan K, Chakravarti A, Gomber S. Systematic review and meta-analysis of randomized controlled trials on the role of mometasone in adenoid hypertrophy in children. Int J Pediatr Otorhinolaryngol. 2015;79(10):1599-608. doi: 10.1016/j.ijporl.2015.07.009.

3. Franco LP, Souki BQ, Cheib PL, Abrão M, Pereira TBJ, Becker HMG, et al. Are distinct etiologies of upper airway obstruction in mouth-breathing children associated with different 
cephalometric patterns? Int J Pediatr Otorhinolaryngol. 2015;79(2):223-8. doi: 10.1016/j.jpporl.2014.12.013.

4. Ardehali MM, Zarch VV, Joibari ME, Kouhi A. Cephalometric assessment of upper airway effects on craniofacial morphology. J Craniofac Surg. 2016;27(2):361-4. doi: 10.1097/ SCS.0000000000002388.

5. Silveira W, Mello FCQ, Guimarães FS, Menezes SLS. Alterações posturais e função pulmonar de crianças respiradoras bucais. Braz J Otorhinolaryngol [Internet]. 2010 [acesso em 17 ago. 2017];76(6):683-6. Disponível em: https://goo.gl/7UUXYd

6. Okuro RT, Morcillo AM, Sakano E, Schivinski CIS, Ribeiro MAGO, Ribeiro JD. Capacidade ao exercício, mecânica respiratória e postura em respiradores bucais. Braz J Otorhinolaryngol [Internet]. 2011 [acesso em 17 ago. 2017];77(5):656-62. Disponível em: https://goo.gl/BYC7NS

7. Sforza C, Colombo A, Turci M, Grassi G, Ferrario VF. Induced oral breathing and craniocervical postural relations: an experimental study in healthy young adults. Cranio. 2004;22(1):21-6. doi: 10.1179/crn.2004.004.

8. Milanesi JM, Borin G, Corrêa ECR, Silva AMT, Bortoluzzi DC, Souza JA. Impact of the mouth breathing occurred during childhood in the adult age: biophotogrammetric postural analysis. Int J Pediatr Otorhinolaryngol. 2011;75(8):999-1004. doi: 10.1016/j.ijporl.2011.04.018.

9. Teixeira RUF, Zappelini CEM, Alves FS, Costa EA. Avaliação do peak flow nasal inspiratório como método objetivo de mensuração do fluxo de ar nasal. Braz J Otorhinolaryngol [Internet]. 2011 [acesso em 17 ago. 2017];77(4):473-80. Disponível em: https://goo.gl/nzg95k

10. Bezerra TF, Pádua FG, Pilan RR, Stewart MG, Voegels RL. Cross-cultural adaptation and validation of a quality of life questionnaire: the nasal obstruction symptom evaluation questionnaire. Rhinology. 2011;49(2):227-31. doi: 10.4193/ Rhino10.019.

11. Souza JA, Pasinato F, Corrêa ECR, Silva AMT. Global body posture and plantar pressure distribution in individuals with and without temporomandibular disorder: a preliminary study. J Manipulative Physiol Ther. 2014;37(6):407-14. doi: 10.1016/j.jmpt.2014.04.003.

12. Bolzan GP, Silva AMT, Boton LM, Corrêa ECR. Estudo das medidas antropométricas e das proporções orofaciais em crianças respiradoras nasais e orais de diferentes etiologias. Rev Soc Bras Fonoaudiol [Internet]. 2011 [acesso em 17 ago. 2017];16(1):85-91. Disponível em: https://goo.gl/Beilks

13. Weber P, Corrêa ECR, Milanesi JM, Soares JC, Trevisan MA. Craniocervical posture: cephalometric and biophotogrammetric analysis. Braz J Oral Sci [Internet]. 2012 [acesso em 17 ago. 2017];11(3):416-21. Disponível em: https:// goo.gl/9fZVLG

14. Sociedade Brasileira de Pneumologia e Tisiologia. Diretrizes para testes de função pulmonar. J Bras Pneumol. 2002;28(3):S1-S238.

15. American Thoracic Society. Lung function testing: selection of reference values and interpretative strategies. Am Rev Respir Dis. 1991;144(5):1202-18. doi: 10.1164/ajrccm/144.5.1202.

16. Trevisan MA, Bellinaso JH, Pacheco AB, Augé LB, Silva AMT, Corrêa ECR. Modo respiratório, patência nasal e dimensões palatinas. CoDAS. 2015;27(2):201-6. doi: 10.1590/2317-1782/20152014177.

17. Ibiapina CC, Andrade CR, Camargos PAM, Alvim CG, Cruz AA. Reference values for peak nasal inspiratory flow in children and adolescents in Brazil. Rhinology. 2011;49(3):304-8. doi: 10.4193/Rhino10.266.

18. Landis JR, Koch GG. The measurement of observer agreement for categorical data. Biometrics 1977;33(1):159-77.

19. Chan YH. Biostatistics 104: correlational analysis. Singapore Med J [Internet]. 2003 [acesso em 17 ago. 2017];44(12):6149. Disponível em: https://goo.gl/MhDfCs

20. Weber P, Corrêa ECR, Ferreira FS, Milanesi JM, Trevisan MA. Análise da postura craniocervical de crianças respiradoras bucais após tratamento postural em bola suíça. Fisioter Pesq [Internet]. 2012 [acesso em 17 ago. 2017];19(2):109-14. Disponível em: https://goo.gl/pf9xkM

21. Huggare JA, Laine-Alava MT. Nasorespiratory function and head posture. Am J Orthod Dentofacial Orthop. 1997;112(5):507-11.

22. Tecco S, Capuli S, Festa F. Evaluation of cervical posture following palatal expansion: a 12-month follow-up controlled study. Eur J Orthod. 2007;29(1):45-51. doi: 10.1093/ejo/cjl021.

23. Cuccia AM, Lotti M, Caradonna D. Oral breathing and head posture. Angle Orthod. 2008;78(1):77-82. doi: 10.2319/011507-18.1.

24. Corrêa ECR, Bérzin F. Mouth breathing syndrome: cervical muscles recruitment during nasal inspiration before and after respiratory and postural exercises on swiss ball. Int J Pediatr Otorhinolaryngol. 2008;72(9):1335-43. doi: 10.1016/j. ijporl.2008.05.012.

25. Melo DL, Santos RVM, Perilo TVC, Becker HMG, Motta AR. Avaliação do respirador oral: uso do espelho de Glatzel e do peak nasal inspiratory flow. CoDAS 2013;25(3):236-41. doi: 10.1590/S2317-17822013000300008.

26. Ottaviano G, Scadding GK, Scarpa B, Accordi D, Staffieri A, Lund VJ. Unilateral peak nasal inspiratory flow, normal values in adult population. Rhinology. 2012;50(4):386-92. doi: 10.4193/Rhino12.071.

27. Mozzanica F, Urbani E, Atac M, Scottà G, Luciano K, Bulgheroni $C$, et al. Reliability and validity of the italian nose obstruction symptom evaluation (I-NOSE) scale. Eur Arch Otorhinolaryngol. 2013;270(12):3087-94. doi: 10.1007/ s00405-013-2426-z.

28. Larrosa F, Roura J, Dura MJ, Guirao M, Alberti A, Alobid I. Adaptation and validation of the spanish version of the Nasal Obstruction Symptom Evaluation (NOSE) scale. Rhinology. 2015;53(2):176-80. doi: 10.4193/Rhin14.137.

29. Zicari AM, Occasi F, Montanari G, Indinnimeo L, De Castro G, Tancredi G, et al. Intranasal budesonide in children affected by persistent allergic rhinitis and its effect on nasal patency and Nasal Obstruction Symptom Evaluation (NOSE) score. Curr Med Res Opin. 2015;31(3):391-6. doi: 10.1185/03007995.2015.1009532.

30. Yilmaz MS, Guven M, Akidil O, Kayabasoglu G, Demir D, Mermer $\mathrm{H}$. Does septoplasty improve the quality of life in children? Int J Pediatr Otorhinolaryngol. 2014;78(8):1274-6. doi: 10.1016/j.ijporl.2014.05.009. 